\title{
The Currency Exposure and Syariah Compliant Status under Different Time Domains: Insights from Maximal Overlap Discrete Wavelet Transformation (MODWT) Analysis
}

\author{
Hishamuddin Abdul Wahab*, Wan Nur Rahini Aznie Zainudin, Sharifah Fairuz Syed Mohamad, \\ Asmah Mohd. Jaapar
}

Faculty of Science and Technology, Universiti Sains Islam Malaysia, 71800 Bandar Baru Nilai, N. Sembilan, Malaysia

Received November 18, 2020; Revised June 29, 2021; Accepted July 8, 2021

\begin{abstract}
Cite This Paper in the following Citation Styles
(a): [1] Hishamuddin Abdul Wahab, Wan Nur Rahini Aznie Zainudin, Sharifah Fairuz Syed Mohamad, Asmah Mohd. Jaapar, "The Currency Exposure and Syariah Compliant Status under Different Time Domains: Insights from Maximal Overlap Discrete Wavelet Transformation (MODWT) Analysis" Universal Journal of Accounting and Finance, Vol. 9 , No. 4, pp. 828 - 840, 2021. DOI: 10.13189/ujaf.2021.090429.
\end{abstract}

(b): Hishamuddin Abdul Wahab, Wan Nur Rahini Aznie Zainudin, Sharifah Fairuz Syed Mohamad, Asmah Mohd. Jaapar (2021). The Currency Exposure and Syariah Compliant Status under Different Time Domains: Insights from Maximal Overlap Discrete Wavelet Transformation (MODWT) Analysis. Universal Journal of Accounting and Finance, 9(4), 828 - 840. DOI: 10.13189/ujaf.2021.090429.

Copyright $\bigcirc 2021$ by authors, all rights reserved. Authors agree that this article remains permanently open access under the terms of the Creative Commons Attribution License 4.0 International License

\begin{abstract}
The rise of the Islamic capital market in the emerging economy of Malaysia over the past few decades motivates us to investigate the impact of the Syariah compliant status on the level of exchange rate exposure. The Syariah compliant status implies that a company should use a minimal level of debt as capital to finance its operations. Given this, it is hypothesized that Syariah compliant firms should exhibit lower levels of exchange rate exposure than their counterparts, supported by the strong theoretical connection between interest rate and exchange rate. In terms of specification, previous efforts in pricing exchange risk failed to capture the true size of exposure due to the use of single time domain in traditional model. To cater the bias in estimation, this study intends to calculate multi-horizon exchange rate exposure based on maximal overlap discrete wavelet transformation to decompose single series into multiple time domains. The financial risk analysis involves 30 listed non-financial individual stocks in Malaysia having different Syariah compliant status from November 2013 until May 2018. As a result, the study finds no significant difference in currency exposure between Syariah compliant and non-Syariah compliant stocks. Secondly, it is found that the
\end{abstract}

extent of currency exposure and the percentage of exposed firms exhibit non-homogenous trend across different time scales where large amount of exposure is concentrated at higher scale. From policy implications, the study suggests that Syariah compliant firms and non-Syariah compliant firms share the same exchange risk profile where exchange risk management routine is expected to be identical for both groups. Besides, the enhanced level of exposure at higher scale requires vigorous financial risk hedging strategies especially within widened investment interval.

Keywords Currency Exposure, Maximal Overlap Discrete Wavelet Transformation, Syariah Compliant Firms

\section{Introduction}

Since the abolishment of the Bretton Wood fixed exchange rate system in the 1970s, the issue of exchange rate risk remains relevant until now. The exchange risk can be defined as the effect of exchange rate movements 
on firm's cash flow which could adversely affect firm's value, performance, operations, competitiveness, growth and market share. Currency exposure (exchange rate risk) can be easily quantified under regression framework where the currency exposure is calculated as the slope between changes in exchange rate and changes in firm value (Adler and Dumas [1]). The sensitivity of firm value towards exchange rate movements is found to be much higher and relevant for developing regions due to the enhanced economic openness and the least use of hedging instruments (Bacha et al. [2], Abdul Wahab et al. [3]).

Despite a significant volume of studies have been devoted in investigating the incidence of exchange rate exposure within developed economies (Jorion [4], Bartram and Bodnar [5]), there has been a little-noted but potentially highly significant level of exposure faced by Malaysian multinational corporations. Malaysia provides a perfect setting for small open economy with a significant portion of foreign trade activities. Besides market openness, Malaysia is selected because of the significant development of Islamic finance over the past few decades. So far, Malaysia is on the right track towards becoming a leading global Islamic finance service provider. According to the Reuters Islamic Finance Development Indicator 2018, Malaysia ranked first place as the most developed Islamic finance market, followed by Bahrain and the United Arab Emirates (UAE). The speedy growth of the Islamic Finance market in Malaysia is strongly supported by accommodative policies and supports from the government as well as strong development in Islamic finance institutions.

The Islamic financial system adopts interest-free system in every aspect of financial activities as well as prohibition in dealing with any activities which are against the Islamic law (Syariah). In achieving the target to be the hub of Islamic finance in the region, the Malaysian government provides supporting initiatives in expanding Islamic financial products and services ranging from banking activities, insurance, financing, investment, wealth management and many more. There are several qualifications need to be fulfilled for a stock to be Syariah compliant which are the least use of debt in operations and financing as well as the permitted business activities under the Syariah spectrum. The least use of debt among Syariah compliant firms (SCF) has motivated us to study the influence of Syariah compliant status on the exchange rate exposure.

As of May 2018, about 23\% of securities in Bursa Malaysia constituted non-Syariah compliant securities which were concentrated in Industrial products and trading services industries. One of the salient criteria that leads to non-Syariah compliance is the inability to satisfy the financial ratio benchmark where interest-bearing debts over total assets ratio within a company's statements of financial position exceed 33\% threshold. Several studies have examined the strong influence of leverage (debt) on the extent of exchange rate exposure. For instance, Chow and Chen [6] examined the role of leverage on the extent of exchange rate exposure of 1110 listed Japanese firms on the Tokyo Stock Exchange. Consequently, the study found that firms with high leverage and low liquidity tend to have greater exchange risk exposure. Another study by Aabo [7] found positive effect of foreign debt in determining exchange risk hedging policies of 117 non-financial Danish firms. Accordingly, under the International Fisher effect, there is strong connection between interest rate and exchange rate. This strong nexus between interest rate and exchange rate implies that low geared firms (Syariah compliant firms) should exhibit lower levels of exchange rate exposure than their counterparts. However, this postulate needs to be further tested in the subsequent section.

Another important issue of the study touches on the influence of time horizon in determining the level of exposure. Previous studies adopted single time domain analysis in quantifying exchange risk which might be suffering bias in estimation. Given the dynamic and time varying nature of exchange risk, the classical assumption of the time-invariant currency exposure in a single time domain appears to be inappropriate. The capital market contains different players encompassing investors, traders, speculators and arbitrageurs with different investment holding periods. Some small retailers focus on short-term gains while institutional investors usually focus on stable and long-term gains. Given the heterogeneity in investment intervals, it is important to decompose single time series into several time domains to cater for different groups of investors. Besides, the reliance towards single domain information on exchange rate exposure measures could lead to invalid risk management decision making. By taking scaling quantity into account, the scale dependent exchange rate risk could help in improving risk management with more timely and accurate hedging strategies ranging from short scale risk management measures to longer horizons.

Given all the issues above, the main objective of the study is to estimate the level of exchange rate exposure of Syariah and non-Syariah compliant firms under different time domains using maximal overlap discrete wavelet transformation (MODWT) approach. The absence of studies focusing on the level of exposure of Syariah compliant firms provides valuable information to firm managers and stakeholders to better understand the nature of exchange risk exposure between the two groups. In addition, it provides information on whether Syariah compliant status could be an important factor of exchange rate exposure. Besides, the information on the multiscale exchange rate exposure provides better risk hedging strategies according to the specific time domain. The scale dependent exposure offers useful information for strategic asset allocation among heterogeneous investors. 


\subsection{Background of Currency Exposure}

Exchange rate risk has become growing cause on most international financial events that leads to financial and economic crisis (Jeon et al. [8]). However, a little doubt was still cast on the existence of currency risks (Lan et al. [9]). With the glitch in Bretton Woods Agreement in 1973, the exchange rate risk had escalated to where currencies were left to float and fluctuate, resulting in more significant gains and losses if no risk management is put in place (Bernoth \& Herwartz [10]). This is especially true when exchange rate directly affects financial assets and liabilities of firms that are denominated in foreign currency and firms with foreign operations. The foreign exchange rates movements have more effects on these firms (Zarei et al. [11]). Hence, the foreign exchange risk needs to be addressed appropriately to avoid other significant negative consequences to these operating firms.

Amongst abundant macroeconomic factors used to determine the competitiveness of a company, exchange rate policies seem to be the important one since they would affect the cash flows and value of companies. Changes in companies' cash flows, net cash flow and market value are some of the mechanisms that contributed to variation in the exchange rate. The exchange rate exposure can be classified as transaction exposure, translation exposure and economic exposure (Eun and Resnick [12]). When a company's contractual cash flows denominated in foreign currencies are exposed to unexpected exchange rate changes, the company is experiencing transaction exposure. However, when a company consolidated financial statements are affected by changes in the exchange rate, the company is exposed to translation exposure. This exposure can be reduced by raising debt in the equivalent currency to provide a natural balance sheet on consolidation or by entering into an offsetting currency derivative contract (Haris and Kaur [13]). For the purpose of this paper, economic exposure is the main focus since it is related to the extent to which the value of a company would be affected by unexpected changes in the exchange rates. In positive economic outlook, the home currency debt with currency swaps can be used on either foreign or home currency debt financing while in negative economic outlook, the foreign currency debt financing dominates (Mahadevan [14]).

Studies in currency exposure mainly focused on either market or industry level, although some had focused on company level exposure. In a study by Abdalla and Murinder [15], unidirectional causality from exchange rates to stock prices are found in all sampled countries, except the Philippines. However, the currency exposures seem to have a negative impact on the sector's stock returns in Indonesia and Philippines based on banking sector data in five East Asian countries during the Asian financial crisis, Kho and Stulz [16]. In countries with fixed exchange rate against another currency, a study by
Parsley and Popper [17] found they have no less exposure to other currencies. In another study in the emerging market, Kiymaz [18] found the Turkish Lira experiencing a depreciation against foreign currencies between March and April 1994. This evidence was based on a sample of 109 Turkish firms between January 1991 to December 1998. The study found that more than half of the firms have a significant effect of the foreign exchange rate exposure due to the foreign involvement (export and import). In a survey conducted by Ito et al. [19] on all Tokyo Stock Exchange listed firms in 2009, they also found that high dependency on foreign sales leads to greater currency exposure.

\subsection{The Incidence of Exchange Rate Exposure in Malaysia Market}

Since the introduction of the flexible exchange rate system in 1973, the exchange rate has shown to be more volatile (Bank Negara Malaysia [20]). This is followed by a steady process of liberalizing capital account transactions and de-regulating the financial system between 1978 to 1989 (Hui-Nee [21]). Such situations had caused the cash flows of Malaysian firms to be more vulnerable towards exchange rate movements and the value of the currency of major trade partners such as the United States, Japan, Europe and East Asian countries. The Asian Crisis in 1997 had showcased the vulnerability of Malaysia's economy towards foreign currency exposure; which motivated more studies in emerging markets.

There seems to be mixed findings on the empirical studies conducted in developed countries. In a study by Doidge et al. [22], the study gauged the exchange rate exposure across 21 developed and 29 developing countries. The regression analysis results showed that currency exposures are greater in emerging markets than in developed markets. A more consistent result can be obtained in a study by Ramasamy [23] that found 56 out of 146 multinationals firms in Malaysia before and during the Asian financial crises to have a significant exposure to foreign exchange exposure. While, a study by Othman et al. [24] that investigated the relationship between exchange rate changes and stock index changes before and during the currency turmoil also found inconclusive evidence on the fluctuation in Ringgit against any influence on the market movement, or vice versa.

\subsection{Background and Growth of Islamic Capital Market in Malaysia}

The capital market has developed the same way as the banking system. Specifically, the Islamic side of capital markets historically emerged due to the conventional features such as riba, maysir and gharar which are deemed prohibited in the Syariah perspective. Apart from its crucial role in generating growth in the economy, the Islamic capital market (ICM) works side by side as a 
complementary function to Islamic banking to broaden Islamic financial markets. In general, ICM in Malaysia consists of three main divisions which include equity, sukuk and mutual funds.

In Malaysia, the ICM development has been quite remarkable, where its emergence was sparked by two major events: the Asian financial crisis (1997) and liquidity issues in the Islamic finance industry (Wan Abdullah et al. [25]). In order to achieve its goal of becoming the world's Islamic financial center, Malaysia has paved its financial development successfully with market infrastructure and support from the government (Herzi [26]). Basically, regulatory bodies for ICM in Malaysia include Bursa Malaysia, Securities Commission and Labuan Offshore Financial Services Authority (LOFSA). At the same time, the ICMD and the SAC are important supporting bodies to enhance the Islamic components which stands as a reference center for all issues concerning Syariah-compliant matters.

Tracing back its history, the ICM in Malaysia started to develop after the 1990s, during the second to the third phase of growth in the Islamic finance industry (Yakcop [27]) During the second phase, which was known as the 'phase of acceptance' many entities had sourced their funds from the capital market to support their finance operations. Many pioneering achievements occurred during this phase, where in 1993 the first Islamic equity trust fund was established under the name of "Arab Malaysian Tabung Ittikal". A year after, the first Islamic stockbroking company was established, which was BIMB Securities Sdn. Bhd. To help regulate the ICM at the time, a separate unit under the Securities Commission was formed. This unit later evolved into a separate department (Islamic Capital Market Department - ICMD) in 1995 and the Syariah Advisory Council (SAC) was established in 1996. Some of the earlier permissible features that allow the growth of ICM include the $33 \%$ threshold of total assets on debt bearing securities and the permissibility of investing in securities from companies with less than $5 \%$ percent of the interest income (Elfakhani et al. [28]), allowing the ICM to flourish at the beginning phase.

As the advancement of the ICM was seen promising despite its infancy, the government under the Ministry of Finance launched a detailed master plan to support this agenda in 2001. The master plan consisted of new formulation of recommendations to enhance Malaysia's position as a center of ICM activities. From 2000 onwards, the ICM witnessed several milestones which further enhanced its development throughout the country. During these few years, new innovations have been taken out which cover securities including debt and equity. In 2002, the first global corporate Islamic bond was issued by Kumpulan Guthrie Berhad, where had opened many paths to further access to the capital market. In 2004, Malaysia was given recognition as the center of the Islamic capital market when the International Finance Corporation issued the first Ringgit denominated Islamic bond (Securities Commission 2004 [29]).

Over the period of ten years (2000 to 2010), a tremendous growth in the ICM was recorded. The size of ICM in Malaysia over this period tripled and experienced about $13.6 \%$ growth annually. This has brought phenomenal growth to the ICM in Malaysia with its size increasing at a rate of $16.3 \%$ annually. By the end of 2012, it has already reached an amount of RM 1.42 trillion. With regards to Islamic equities globally, the total of Islamic funds with assets under management was 876 in 2011 which amounted to USD 60 Billion (Grewal [30]). In 2011, up to $46.9 \%$ of the funds were invested in the Syariah compliant securities, while around $22.2 \%$ were invested in money market instruments. The balance was spread among sukuk, commodities, real estate and mixed assets. As a result, Malaysia was considered the most active and liquid equity market, experiencing a total of 817 Islamic securities representing $89 \%$ of the listed securities in 2012 . In relation to mutual funds, Malaysia already achieved a total of 169 funds, holding a value of almost USD 12 Billion which then brought its position as the second largest market in the Islamic mutual funds industry in 2012 following Saudi Arabia.

Additionally, the market capitalization for Malaysia is far higher compared to countries like Indonesia, Brunei and the U.A.E. As of the end of 2011, Malaysia's figures were USD 300 Billion while Indonesia and the U.A.E. held a market cap of USD 171.4 Billion and USD 40.1 Billion respectively (Najeeb \& Vejzagic [31]). Similarly, in terms of sukuk, Malaysia has been keeping its record as the main issuer which had its total of around USD 234.1 billion worth in this Islamic debt instrument. Over the last decade, the value of sukuk was seen to continuously increasing at a rate of $22.2 \%$ per annum.

\subsection{The Syariah Screening Procedure}

Syariah screening procedure is a process of selecting investments that comply with Syariah principles i.e. to classify the Syariah compliant firms (SCF) and non-Syariah compliant firms (NSCF). Syariah principles have outlined the activity that are forbidden to involve with, such as usury (riba), ambiguity (gharar), gambling (maisir), consumption of alcohol and other non-halal products. In line with the Syariah principles, Muslim investors are prohibited from investing in securities whose earnings and returns were sourced from prohibited activities.

In Malaysia, the duty to screen securities is done by Syariah Advisory Council (SAC) of Securities Commission (SC) of Malaysia. The screening involved all firms listed in Bursa Malaysia. Securities Commission as a market regulator, has the mandate to update and publish the list of Syariah compliant securities twice a year which is in May and November. The list is also known as the SC 
list of Syariah compliant securities. Through the SAC of SC, Malaysia has been practicing two versions of the Syariah screening methodology. The first version introduced in 1995 had been practiced in the Malaysian capital market for 17 years. However, the first version was perceived to be lenient compared to global Syariah index providers (Mat Nor et al. [32]). In response to the international criticism (see Abdul Rahman et al. [33], Pok [34]), the revised Syariah screening methodology came into enforcement on 29 November 2013. Since then, the second version of Syariah screening methodology has served as a guideline for Syariah-concern investors and used by Malaysia Syariah index providers such as FTSE Bursa Malaysia EMAS Syariah Index.

Malaysia's Syariah screening methodology consists of qualitative and quantitative assessments. All listed firms must pass the screening process at both levels. The quantitative assessment is the first screening that determines the percentage contribution of Syariah impermissible activities to total revenue of the firm. The quantitative approach has two-tier benchmarks which are business activity benchmarks and financial ratio benchmarks. The first-tier of business activity benchmarks is also called sector screening. It uses negative screening (Trinks \& Scholtens [35]) to exclude non-halal primary activities firms, and specific benchmarks were applied for mixed business companies i.e. companies that deal with permissible and non-permissible business activities. The ratio of Syariah non-compliant business/activities over the firm's revenue and profit before tax should not exceed the two business activities benchmarks (5\% and 20\%) (See Appendix 1 for the details of Syariah non-permissible activities and the associated benchmarks). After passing the sector screening, the securities must undergo the second-tier quantitative assessment known as financial ratio screening or accounting-based screening. The use of financial ratio benchmarks has long been practiced by global Syariah index makers like Morgan-Stanley Capital International Islamic Index (MSCI Islamic) and Financial-Times Stock Exchange Syariah Index (FTSE-SI). These ratios evaluate the extend of riba and riba-based elements within a firm financial statement. The financial ratios consist of debt over total assets and cash over total assets. Both ratios must be less than $33 \%$ over the firm's total asset to be eligible for Syariah compliant status (Securities Commission Malaysia) [36]. The fact that SCF have lower debt ratios than NSCF, hence could exhibit less exchange rate exposure has motivated us to conduct this study.

After passing the two-tier quantitative assessments, the securities will be subjected to the qualitative screen to oversee the public perceptions towards the image of the firms. For companies with mixed business activities, the SAC has outlined two additional criteria that must be fulfilled to be fit for Syariah compliant status as follows;

a) The public perception towards the image of the firms must be good, AND

b) The primary business activity of the firm is important and is considered allowed for the maslahah (public interest) of Muslims and the country, and the unauthorized elements are very minimal and involve things such as 'итти balwa (common plight and difficult to avoid), 'uruf (custom) and rights of the non-Muslim that is accepted by Islam (Saiti et al. [37]).

For simplicity, the Syariah screening procedure could be illustrated in the following framework;

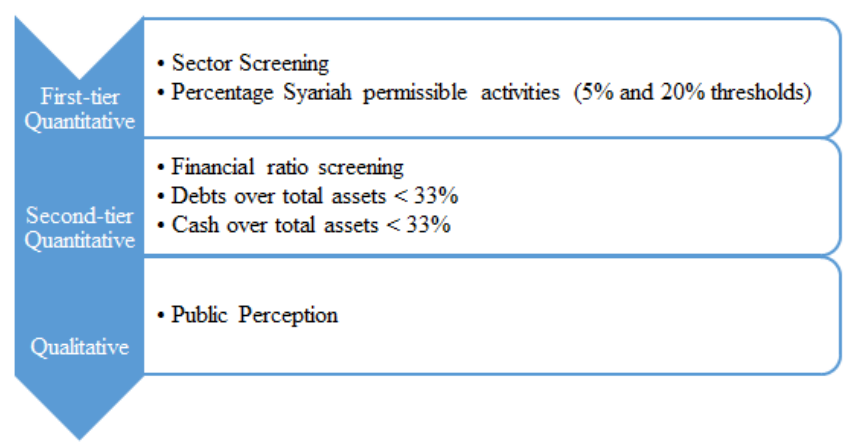

Figure 1. SAC Syariah Screening Methodology effective since 29 November 2013

\subsection{Application of Wavelet in Finance}

The measurement of exchange rate exposure has been dominantly assessed under the regression framework. While the method is useful to gauge the sensitivity of firm value against changes in exchange rates throughout years until today, the examination on the influence of time horizon on the exchange rate exposure could not be done under the traditional regression framework due to the inability of regression analysis to decompose a given time series. Thus, the conventional regression model tends to create bias in estimation due to the homogeneity assumption of exchange risk across different time horizons. To solve the specification issue, the study suggests the combination of wavelet and regression analyses to unveil the scale-dependent exchange rate exposure. Wavelet analysis has been widely used in many financial and economic relationships. The use of wavelet is driven by different decision-making among heterogeneous market participants. The true structure of the dynamic relationship between variables are varies for each time scale and the use of the wavelet tool has assisted in filling the gap in the literature. The use of wavelets can be categorized into several sections which are wavelet transform, long memory stationary process and variance/covariance analyses. The first category covers several past studies including Gencay et al. [38-39] and In and Kim [40]. Next, the second category involves 
analysis in multiscale long-run relationships between variables under the ordinary least square (OLS) framework. Some samples of studies include Jensen [41], Tkacz [42] and Whitcher and Jensen [43]. Further, wavelet decomposition involving economic relationships of income and expenditure has been studied by Ramsey and Lampart [44], scale-dependent Sharpe ratio by Kim and In [45], systematic risk in capital asset pricing model (CAPM) by Gencay et al. [38] and Masih et al. [46]. The last category focuses on unveiling multiscale variance and covariance analysis. The stream of research under this category includes Percival and Walden [47] and Gencay et al. [48]. The application of wavelet in unveiling scale-dependent exchange rate exposure is relatively new in the finance area (Wan Suhaimi et al. [49]).

\section{Methodology}

\subsection{Data}

The study used daily closing rate data on 30 stock prices, daily closing rate of FTSE Bursa Malaysia Kuala Lumpur Composite Index (FBM-KLCI) and the exchange rate MYR/USD in the period from 29 November 2013 to 24 May 2018, giving a sample of 3900 observations for each bi-annual period. The selection of 30 companies was based on several criteria such as the following;

a) Public listed on the Bursa Malaysia (Main Board)

b) Public information (prices) must be available from November 2013 until May 2018

c) Firms must be listed under major non-financial industries (under Datastream classification) in Malaysia comprising Electronics and Electrical, Automobile,Food and Beverages, Chemicals, Oil and gas producers, Metals and mining and General Industrials.

There were 298 firms in the study sample at the initial stage. However, the majority of sample firms constituted Syariah compliant firms. Therefore, for fair analysis, firms must be equally divided into Syariah compliant and non-Syariah compliant. Due to a limited number of non-Syariah compliant firms in the sample (15 firms), thus 15 Syariah compliant firms were selected after satisfying requirements (a) - (c). The starting month of November 2013 was selected because of the new revision of Syariah compliant screening procedure by the securities commission effective on 29 November 2013. The daily market data were collected from Datastream while Syariah compliant status was taken from the bi-annual list issued by the Syariah Advisory Council (SAC) of the Securities Commission Malaysia.

\subsection{Method}

The method could be explained based on three main parts. The first part involved categorizing Syariah compliant firms (SCF) for each bi-annual period based on the SAC report. The information was extracted manually from matching firms in the sample to the list provided by SAC. After each firm was classified in accordance to its Syariah compliant status, the second stage involved transformation on the data series. To deal with non-stationary feature of trended financial data, stock price at time $t\left(P_{t}\right)$, bilateral exchange rate Malaysian Ringgit against the US Dollar at time $t\left(U S D_{t}\right)$ and market index, FTSE Bursa Malaysia Composite Index at time $t$ $\left(\mathrm{P}_{\mathrm{m}, \mathrm{t}}\right)$ were converted into $\log$ difference of price at time $t$ and time $t-1$ as below;

$$
\begin{gathered}
\text { Stock returns, } \quad t=\ln \left(\frac{P_{t}}{P_{t-1}}\right) \\
\text { Market returns, } \quad m, t=\ln \left(\frac{P_{m, t}}{P_{m, t-1}}\right) \\
\text { Exchange Rate Changes, } R U S D_{t}=\ln \left(\frac{U S D_{t}}{U S D_{t-1}}\right)
\end{gathered}
$$

The third stage required wavelet decomposition. The study employed a special class of Maximal Overlap Discrete Wavelet Transformation (MODWT) namely Daubechies transformation to unveil the scaling properties of exchange rate exposure. The study adopted discrete transformation under the assumption of finite length of investment. The finite range scale provided more meaningful results to our study. As aforementioned, the benefits of adopting wavelet transformation are the non-existence of priori distribution assumption and its ability to capture exposure across different scales. The transformed series above were decomposed into 5 wavelet crystals ranging from $d l$ (2-4 days), $d 2$ (4-8 days), $d 3$ (8-16 days), $d 4(16-32$ days) and $d 5$ (32-64 days). This scaling properties reported currency exposure for short term interval (low scale) to widened investment horizon (high scale). To better understand the multiresolution idea of wavelet analysis, one needs to understand wavelet scaling properties ranging from father and mother wavelet. The original return series is represented by a linear combination of wavelet factors as below;

$$
r_{t} \approx \sum_{k} s_{j, k} \phi_{j, k}(t)+\sum_{k} d_{j, k} \psi_{j, k}(t)+\sum_{k} d_{j-1, k} \psi_{j-1, k}(t)+\ldots+\sum_{k} d_{1, k} \psi_{1, k}(t)
$$

Two-dimensional family functions are translated based on the following equations;

$$
\begin{aligned}
\phi_{j, k}(t) & =2^{-j / 2} \phi\left(\frac{t-2^{j} k}{2^{j}}\right) \text { for } \quad j=1 \text { to } J \\
\psi_{j, k}(t) & =2^{-j / 2} \psi\left(\frac{t-2^{j} k}{2^{j}}\right) \text { for } j=1 \text { to } J
\end{aligned}
$$

Where $j$ represents the member of crystals/scales $k$ represents the number of coefficients $2^{j}$ is a sequence of scales for frequency partitioning

It should be noted that as $j$ increases, the factor $2^{j}$ will be expanded accordingly causing translation parameter $2^{j} k$ increases and producing wider translation step. Mother 
wavelet represents high frequency data (detailed part of the series) while father wavelet explains low frequency (smooth part of the series). The wavelet coefficients for smooth part $\left(s_{j, k}\right)$ and deviation part from smooth process $\left(d_{j, k}\right)$ are approximated as below;

$$
\begin{aligned}
s_{j, k} & \approx \int \varphi_{j, k}(t) f(t) d t \\
d_{j, k} & \approx \int \psi_{j, k}(t) f(t) d t
\end{aligned}
$$

The information from wavelet coefficients $s_{j, k}$ and $d_{j, k}$ play significant roles in measuring the contribution of wavelet functions to the overall series. All decomposed series were then regressed using the residual model for each scale $j$ as follows;

$$
\begin{aligned}
R^{j}=a^{j}+\beta_{M}^{j} R_{M}^{j}+ & \beta_{U S D}^{j} R_{U S D}^{j}+\beta_{E U R}^{j} R_{E U R}^{j}+\beta_{G B P}^{j} R_{G B P}^{j} \\
& +\beta_{J P Y}^{j} R_{J P Y}^{j}+e^{j}
\end{aligned}
$$

The heart of the analysis is concentrated on the magnitude, sign and significance of the scale-dependent beta coefficient $\left(\beta_{U S D}^{j}\right)$ (Abdul Wahab [50], Wan Suhaimi et al. [51]). The insignificant (homogeneity) of $\beta_{U S D}^{j}$ across all scale $j$ implies the irrelevance of time scale in measuring exchange rate exposure. On the other hand, the statistical significance of $\beta_{U S D}^{j}$ suggests the multiscale tendency of exchange risk and has significant implications in risk pricing. It is hypothesized that high wavelet scale (widened investment interval) should exhibit high level of exchange rate exposure. However, this priori expectation needs to be tested in the next part. The last stage involves testing the significant influence of Syariah compliant status in determining exchange rate exposure. The second-stage cross-sectional regression was conducted where $\beta_{U S D}^{j}$ was assigned as the dependent variable as below;

$$
\beta_{U S D}^{j}=\alpha_{0 i}+\delta S C F_{i}+e_{i}
$$

$S C F$ represents dummy for Syariah compliant firm $(S C F)$ where $S C F=1$ for a company with Syariah compliant status at a specific sub-period and 0 for others while $\delta$ is the coefficient of SCF dummy. $\alpha_{0 i}$ and $e_{i}$ are the intercepts and cross-sectional error terms respectively.

\section{Results}

\subsection{Empirical Results and Discussion}

Table 1 displays the results of estimated beta coefficients
$\beta_{U S D}^{j}$ for 30 sample firms (combination of SCF and NSCF) for each bi-annual period by regressing individual stock returns with the USD returns. Each $\beta_{U S D}^{j}$ gauges the contribution of scale movement in exchange returns to stock returns. To avoid offsetting effect between positive and negative sign of exposure, the study has segregated the results for both signs.

Several noteworthy information could be extracted from Table 1. First, it could be seen that the beta exposure and percentage of exposed firms display multiscale tendency, where the beta coefficient changes non-monotonically corresponding to each time scale. Generally, beta exposure slightly increases from low scale to high scale for both positive and negative exposure. This increment level of exposure from low time scale to high time scale is economically sensible under the context of relationship between the size of exposure and time holding period. Given this, it is expected that long term investors should embrace greater exposure than short term investors. In line with Gencay et al. [39], the wavelet analysis allows the fragmentation of the unconditional variances and covariances which forming scale dependent beta exposure and caters to specific individual investment intervals. From the finding, the study emphasizes the importance of time scale in exchange risk pricing. Secondly, for effective risk management policies, the study suggests that the foreign exchange risk hedging routine should be concentrated primarily on a widened time horizon (above 30 days). While most firms adopt selective hedging in their risk management policies in terms of the size of exchange rate exposure (the size of foreign sales), firms could take the time horizon of the foreign transaction as one of the requirements for hedging routine. The short time scale might provide a negligible impact on foreign denominated transactions however close monitoring should be done across all time horizons.

For better comprehension, visual inspection on the level of exchange rate exposure could be seen in Figures $2(a)$ to $2(j)$. In general, there is systematic increase from low scale $(D I)$ to high scale (D5) as well at the father wavelet scale (S5). A more interesting result appears that the Syariah compliance status (percentage of SCF) has negligible impact on the level of exposure. For instance, in November 2013 sub-period, $40 \%$ of firms were SCF and showing non-monotonic increases from low scale to high scale. In the same vein, $80 \%$ of firms were SCF during November 2017 sub-period and exhibiting identical trend when there is a rise of exposure from low scale to high scale. 
Table 1. The multiscale exchange rate exposure

\begin{tabular}{|c|c|c|c|c|c|c|c|c|c|}
\hline $\begin{array}{c}\text { Wavelet } \\
\text { Scale* }\end{array}$ & $\begin{array}{c}\text { Average } \\
\text { Beta }\end{array}$ & $\begin{array}{c}\text { Beta } \\
(+)\end{array}$ & Beta (-) & $\begin{array}{c}\% \text { exposed } \\
\text { firms }\end{array}$ & $\begin{array}{c}\text { Wavelet } \\
\text { Scale } \\
\end{array}$ & $\begin{array}{c}\text { Average } \\
\text { Beta }\end{array}$ & $\begin{array}{c}\text { Beta } \\
(+)\end{array}$ & Beta (-) & $\begin{array}{c}\% \text { exposed } \\
\text { firms } \\
\end{array}$ \\
\hline Whole period & & & & & Nov-15 & & & & \\
\hline D1 & -0.2901 & 0.3758 & -0.3925 & $67 \%$ & D1 & -0.0728 & 0.4254 & -0.4537 & $17 \%$ \\
\hline D2 & -0.2814 & 0.0986 & -0.3399 & $37 \%$ & D2 & -0.1882 & 0.3192 & -0.5264 & $20 \%$ \\
\hline D3 & -0.2947 & 0.1933 & -0.4167 & $57 \%$ & D3 & -0.0434 & 0.7482 & -0.9481 & $57 \%$ \\
\hline D4 & -0.3132 & 0.1896 & -0.4961 & $63 \%$ & D4 & 0.4930 & 1.0536 & -0.6281 & $67 \%$ \\
\hline D5 & -0.3878 & 0.1333 & -0.5180 & $60 \%$ & D5 & 0.0295 & 0.7331 & -0.7747 & $80 \%$ \\
\hline S5 & -0.7610 & 0.0102 & -0.8161 & $80 \%$ & S5 & -0.8034 & 1.4059 & -1.7503 & $90 \%$ \\
\hline Nov-13 & & & & & May-16 & & & & \\
\hline D1 & -0.4169 & 0.4958 & -1.4599 & $13 \%$ & D1 & 0.0253 & 0.5712 & -0.5205 & $27 \%$ \\
\hline D2 & -0.0290 & 0.6324 & -1.1714 & $27 \%$ & D2 & -0.1512 & 0.5712 & -0.7036 & $27 \%$ \\
\hline D3 & 0.2393 & 0.9727 & -1.0275 & $43 \%$ & D3 & -0.3796 & 0.5962 & -1.0302 & $37 \%$ \\
\hline D4 & -0.5085 & 1.4278 & -1.3383 & $57 \%$ & D4 & -0.1634 & 0.8094 & -0.9073 & $67 \%$ \\
\hline D5 & -0.7126 & 0.9517 & -1.8221 & $73 \%$ & D5 & 0.2953 & 1.1324 & -0.9605 & $77 \%$ \\
\hline S5 & -1.1205 & 2.8580 & -2.3313 & $80 \%$ & S5 & 0.1410 & 2.5747 & -3.5095 & $83 \%$ \\
\hline $\begin{array}{c}\text { Wavelet } \\
\text { Scale* }\end{array}$ & $\begin{array}{c}\text { Average } \\
\text { Beta }\end{array}$ & $\begin{array}{c}\text { Beta } \\
(+)\end{array}$ & Beta (-) & $\begin{array}{c}\text { \% exposed } \\
\text { firms }\end{array}$ & $\begin{array}{c}\text { Wavelet } \\
\text { Scale } \\
\end{array}$ & $\begin{array}{c}\text { Average } \\
\text { Beta }\end{array}$ & $\begin{array}{c}\text { Beta } \\
(+)\end{array}$ & Beta (-) & $\begin{array}{c}\% \text { exposed } \\
\text { firms }\end{array}$ \\
\hline $\begin{array}{c}\text { Cont. } \\
\text { May-14 } \\
\text { D1 }\end{array}$ & -0.4949 & 0.8622 & -0.9080 & $23 \%$ & $\begin{array}{c}\text { Nov-17 } \\
\text { D1 }\end{array}$ & -0.0516 & 1.4291 & -1.9877 & $13 \%$ \\
\hline D2 & -0.3291 & 0.6225 & -0.8049 & $13 \%$ & D2 & 0.3038 & 1.5289 & -1.2983 & $17 \%$ \\
\hline D3 & -0.6269 & 1.1029 & -1.6283 & $53 \%$ & D3 & -0.5687 & 1.4710 & -2.1284 & $53 \%$ \\
\hline D4 & 0.6876 & 1.4500 & -0.8373 & $50 \%$ & D4 & 0.7250 & 2.1130 & -3.0921 & $50 \%$ \\
\hline D5 & 2.3585 & 2.7175 & -0.8723 & $77 \%$ & D5 & 1.0378 & 2.8192 & -2.5249 & $60 \%$ \\
\hline S5 & -1.1730 & 2.9014 & -2.9192 & $97 \%$ & S5 & -0.7425 & 4.2953 & -3.6591 & $80 \%$ \\
\hline Nov-14 & & & & & May-17 & & & & \\
\hline D1 & -0.4949 & 0.8622 & -0.9080 & $23 \%$ & D1 & -0.1055 & 1.3263 & -1.9779 & $23 \%$ \\
\hline D2 & -0.1993 & 0.3394 & -0.4686 & $3 \%$ & D2 & -0.2512 & 0.8411 & -1.2069 & $17 \%$ \\
\hline D3 & 0.1793 & 0.5113 & -0.5952 & $43 \%$ & D3 & -0.2355 & 1.9440 & -1.9022 & $53 \%$ \\
\hline D4 & 0.6499 & 1.4264 & -0.6913 & $77 \%$ & D4 & -0.9765 & 1.4104 & -1.7030 & $63 \%$ \\
\hline D5 & 0.8649 & 2.0674 & -1.2122 & $73 \%$ & D5 & -0.2813 & 1.5948 & -1.5321 & $73 \%$ \\
\hline S5 & -0.5087 & 0.8783 & -1.7224 & $87 \%$ & S5 & -0.2408 & 1.9272 & -2.4087 & $63 \%$ \\
\hline May-15 & & & & & Nov-17 & & & & \\
\hline D1 & -0.1813 & 0.2522 & -0.5127 & $17 \%$ & D1 & -0.3099 & 0.7759 & -1.2600 & $10 \%$ \\
\hline D2 & 0.2603 & 0.4881 & -0.2712 & $23 \%$ & D2 & -0.3405 & 0.8510 & -1.1348 & $13 \%$ \\
\hline D3 & 0.0452 & 0.5088 & -0.6504 & $37 \%$ & D3 & -0.5420 & 0.9677 & -1.4161 & $37 \%$ \\
\hline D4 & -0.0138 & 0.4968 & -0.7798 & $50 \%$ & D4 & 1.0319 & 1.9945 & -1.2142 & $60 \%$ \\
\hline D5 & 0.3833 & 1.8945 & -1.5929 & $67 \%$ & D5 & 0.6058 & 2.0239 & -2.2305 & $67 \%$ \\
\hline S5 & -0.5769 & 1.8877 & -1.4732 & $87 \%$ & S5 & -1.6727 & 3.6692 & -4.3437 & $73 \%$ \\
\hline
\end{tabular}

*Wavelet scales D1: 2-4 days, D2: 4-8 days, D3: 8-16 days, D4:16-32 days, D5: 32-64 days, S5: Father wavelet 


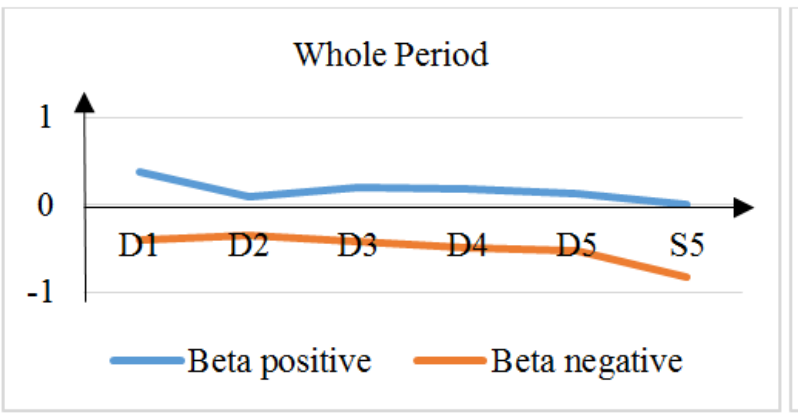

Figure 2(a) Beta exposure for whole period

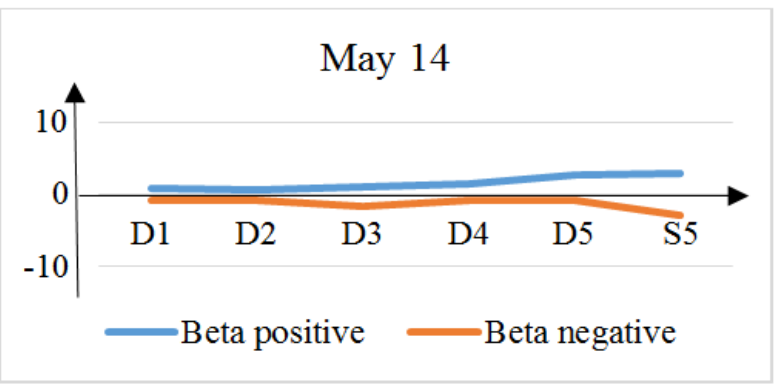

Figure 2(c) Beta exposure for May 14

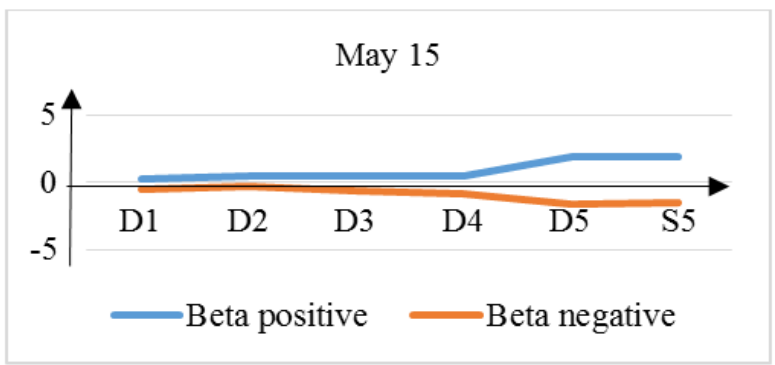

Figure 2(e) Beta exposure for May 15

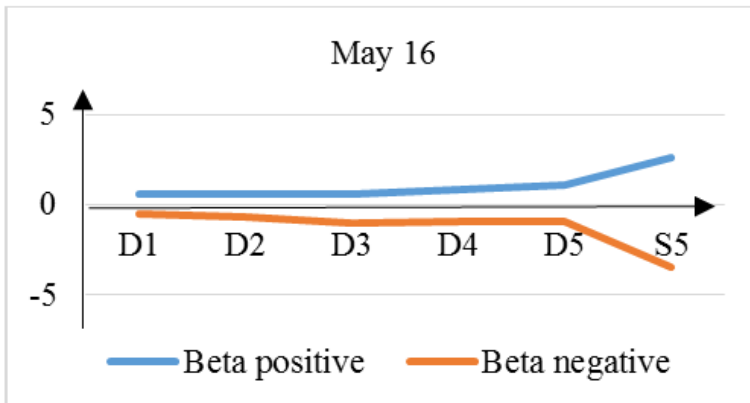

Figure 2(g) Beta exposure for May 16

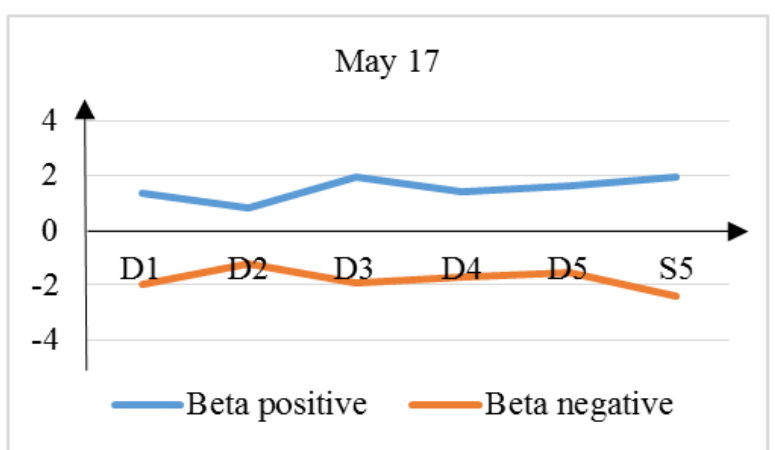

Figure 2(i) Beta exposure for May 17

\section{Nov 13}

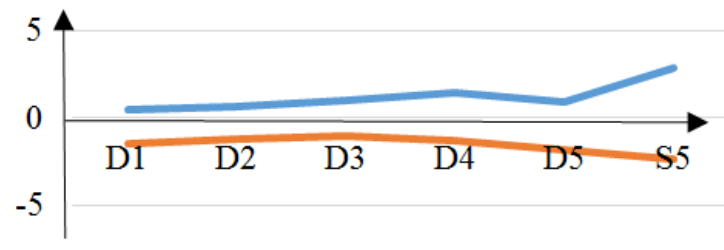

$\longrightarrow$ Beta positive $\longrightarrow$ Beta negative

Figure 2(b) Beta exposure for Nov 13

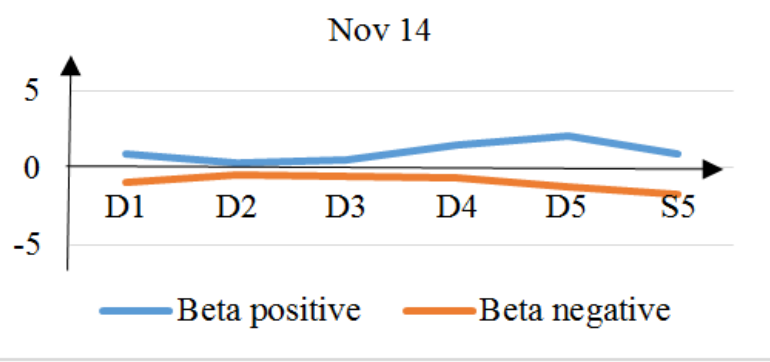

Figure 2(d) Beta exposure for Nov 14

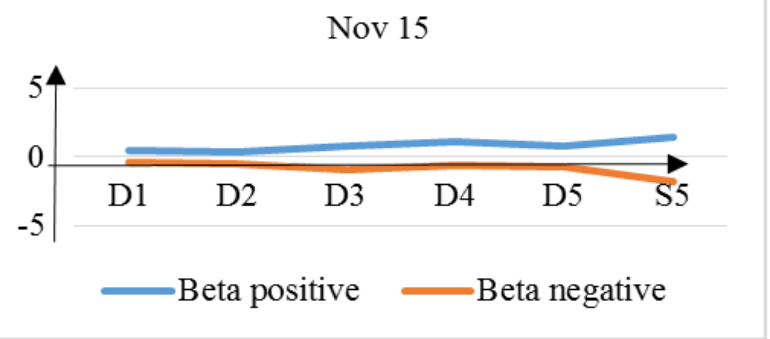

Figure 2(f) Beta exposure for Nov 15

Nov 16

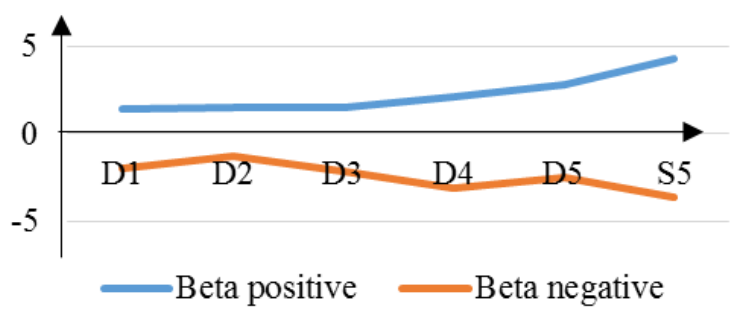

Figure 2(h) Beta exposure for Nov 16

Nov 17

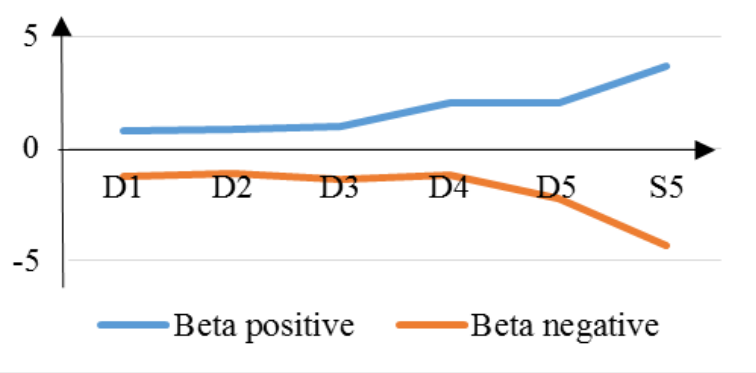

Figure 2(j) Beta exposure for Nov 17 
Table 2. The significance of SCF dummies

\begin{tabular}{c|c|c}
\hline Wavelet scales* & SCF Dummy & p-value \\
\hline D1 & 0.0455 & 0.7645 \\
D2 & -0.0232 & 0.8589 \\
D3 & 0.3702 & 0.0141 \\
D4 & 0.1578 & 0.3794 \\
D5 & 0.2802 & 0.2151 \\
S5 & 0.3343 & 0.2413 \\
\hline
\end{tabular}

*Wavelet scales D1: 2-4 days, D2: 4-8 days, D3: 8-16 days,

D4:16-32 days, D5: 32-64 days, S5: Father wavelet

Table 3. The significance of SCF dummies for each sub-period

\begin{tabular}{|c|c|c|c|c|c|c|}
\hline Period & D1 & D2 & D3 & D4 & D5 & S5 \\
\hline \multirow[t]{2}{*}{ Nov-13 } & -0.0563 & -0.0085 & -0.0717 & 0.5056 & 0.1596 & 0.3153 \\
\hline & $(0.919)$ & $(0.9842)$ & $(0.8764)$ & (0.5198) & (0.8168) & $(0.7745)$ \\
\hline \multirow[t]{2}{*}{ May-14 } & -0.5130 & 0.2960 & 0.2326 & -0.4702 & -0.7034 & 1.1746 \\
\hline & (0.1996) & $(0.3589)$ & $(0.7207)$ & $(0.4228)$ & $(0.5526)$ & (0.3732) \\
\hline \multirow[t]{2}{*}{ Nov-14 } & -0.3670 & 0.2633 & 0.2138 & -0.6171 & 0.3798 & -0.8768 \\
\hline & $(0.3612)$ & $(0.1459)$ & $(0.3784)$ & $(0.191)$ & $(0.6441)$ & $(0.133)$ \\
\hline \multirow[t]{2}{*}{ May-15 } & -0.1347 & 0.0879 & 0.0946 & 0.3804 & 0.6442 & -0.5152 \\
\hline & $(0.5213)$ & $(0.6508)$ & $(0.7449)$ & $(0.2349)$ & $(0.4736)$ & $(0.4652)$ \\
\hline \multirow[t]{2}{*}{ Nov-15 } & 0.0045 & 0.2517 & 0.4158 & -0.4930 & 0.4855 & 0.4691 \\
\hline & $(0.9849)$ & (0.3308) & (0.3409) & (0.2698) & $(0.1724)$ & $(0.5543)$ \\
\hline \multirow[t]{2}{*}{ May-16 } & 0.0409 & -0.0703 & 0.6056 & -0.1599 & -0.3518 & -2.1276 \\
\hline & $(0.8718)$ & $(0.8222)$ & $(0.1595)$ & (0.6995) & (0.4954) & $(0.1365)$ \\
\hline \multirow[t]{2}{*}{ Nov-16 } & 0.4093 & -0.3726 & -0.6961 & -0.6430 & 0.5952 & 1.1625 \\
\hline & $(0.6601)$ & $(0.6335)$ & $(0.4671)$ & (0.6559) & $(0.6856)$ & (0.6318) \\
\hline \multirow[t]{2}{*}{ May-17 } & -0.2611 & -0.0269 & -0.5555 & -0.4952 & -1.0281 & -2.2822 \\
\hline & $(0.7737)$ & $(0.9643)$ & $(0.5775)$ & $(0.5282)$ & $(0.2358)$ & $(0.0812)$ \\
\hline \multirow[t]{2}{*}{ Nov-17 } & 0.0524 & 0.1246 & 0.3077 & $1.7068^{*}$ & 1.5190 & 2.8654 \\
\hline & (0.938) & (0.8534) & (0.6809) & $(0.0955)$ & (0.2047) & $(0.236)$ \\
\hline
\end{tabular}

To further stress the difference between SCF and NSCF, second stage cross-sectional regression analysis is conducted to test the significance of SCF to the level of exposure. Based on Table 2, there is a clear indication that SCF does not play significant role in determining the level of exposure. It could be seen that the p-values of SCF dummies are greater than 5\% significant level during each time scale $\mathrm{j}$ (excepting scale D3). This result lends us to a conclusion that SCF and NSCF show the identical exchange risk profile, supporting the law of one price. Further, there's no basis to expect that the way SCF manages exchange risk will be different than NSCF (Abdul Wahab [52]). The most important elements contributing to exchange risk depend on the extent of foreign trade involvements, business profiles and hedging intensities. To check the robustness of the results, the study embarks multiscale regression following each time period. The significance of SCF is tested for each time scale in accordance to its sub-period. Table 3 displays the coefficient of SCF dummies as well as p-values (in parenthesis). It could be seen clearly seen that all p-values assigned to each SCF dummies display large value above 5\% significance level. This finding stresses the irrelevance of SCF factor in determining exchange rate exposure.

\section{Conclusions}

The major innovation of the study lies on the use of maximal overlap discrete wavelet transformation (MODWT) in unveiling scale-dependent exchange rate exposure of Syariah compliant firms (SCF) and non-Syariah compliant firms (NSCF) in Malaysia. Our empirical results indicate that Syariah compliant status has negligible impact in influencing exchange rate exposure. The result suggests that both types of firms (SCF and NSCF) have the same exchange risk profile. Several reasons can be justified. First, it seems that 
exchange risk factors are closely dependent on the nature of business profiles, price elasticity, trade activities, the extent of hedging practices and market conditons (supply and demand) (Sinaga et al. [53]). Secondly, there is no basis to expect different exchange risk management programs between Syariah compliant and non-Syariah compliant firms. Despite growing concerns on the permissibility of financial derivatives, many Syariah scholars are in view that the use of financial hedging for the sole hedging purpose is allowed as long as the financial instruments are not used for speculative activities. Third, the cost of fund for Syariah compliant stocks is benchmarked to LIBOR, the same way as conventional stocks. Thus, there is no basis to expect distinct feature of exchange risk exposure between Syariah compliant and non-Syariah compliant stocks as both assets share the same exchange risk pricing and supports the law of one price. In terms of wavelet analysis, there is multiscale tendency of exchange rate exposure where large high level of exposure is largely concentrated in the high scale compared to low scale. The result meets economic sense as the longer holding period is associated with greater uncertainty. Given this, an intuitively plausible strategy might be to put vigorous hedging activities for a longer period (preferably more than a month) so that the risk emanating from exchange risk can be effectively hedged.

\section{Acknowledgement}

We would like to thank Universiti Sains Islam Malaysia for providing us with invaluable support and research funding under the code: PPPI/FST/0118/051000/16518.

\section{Appendix}

\section{Appendix 1. Two-tier Quantitative Assessment}

\begin{tabular}{|c|c|c|}
\hline $\begin{array}{l}\text { Quantitative } \\
\text { Assessment }\end{array}$ & Benchmark & Activity \\
\hline \multirow[t]{2}{*}{$\begin{array}{c}\text { Business } \\
\text { activity } \\
\text { benchmarks }\end{array}$} & $5 \%$ & $\begin{array}{l}\text { To measure the level of mixed contributions from activities that are clearly prohibited in Islam such as: } \\
\text { 1. } \\
\text { 2. Conventional banking and lending } \\
\text { 3. } \quad \text { Gonventional insurance } \\
\text { 4. Liquor and liquor-related activities } \\
\text { 5. } \quad \text { Pork and pork-related activities } \\
\text { 6. Non-halal food and beverages } \\
\text { 7. } \quad \text { Syariah non-compliant entertainment } \\
\text { 8. Interest income from conventional accounts and instruments, including dividends from investments } \\
\text { in Syariah non-compliant instruments and interest income awarded from a court judgement or arbitrator } \\
\text { 9. } \quad \text { Tobacco and tobacco-related activities } \\
\text { 10. } \quad \text { Other activities deemed non-compliant according to Syariah principles } \\
\end{array}$ \\
\hline & $20 \%$ & $\begin{array}{l}\text { To measure the level of mixed contribution activities that generally permissible according to Syariah and } \\
\text { consist of aspect maslahah (public interest), but may attached with other activities that deemed as } \\
\text { non-Syariah permissible such as: } \\
\text { 1. Share trading } \\
\text { 2. Stockbroking business in Syariah non-compliant activities } \\
\text { 3. } \quad \text { Rental received from Syariah non-compliant activities } \\
\text { 4. } \quad \text { Other activities deemed non-compliant to Syariah }\end{array}$ \\
\hline \multirow{2}{*}{$\begin{array}{l}\text { Financial ratio } \\
\text { benchmarks }\end{array}$} & $33 \%$ & $\begin{array}{l}\text { Leverage compliance: } \\
\text { Debt over Total Assets* }\end{array}$ \\
\hline & $33 \%$ & $\begin{array}{l}\text { Cash compliance: } \\
\text { Cash or cash equivalent over Total Assets** }\end{array}$ \\
\hline
\end{tabular}

*the calculation includes the interest-bearing debt of the conventional accounts, and excludes Islamic financing such as sukuk

** the calculation includes the cash placed in conventional accounts and instruments, and excludes the one placed in the Islamic account Source: Securities Commission of Malaysia (2019) 


\section{REFERENCES}

[1] Adler, M., and Dumas, B. "Exposure to currency risk: definition and measurement." Financial Management 13, (1984): 41-50.

[2] Bacha, O.I., Mohamad, A., Syed Mohd Zain, S.R., and Mohd Rasid, M.E.S. "Foreign exchange exposure and impact of policy switch. The case of Malaysian listed firms." Applied Economics 45, no. 20 (2013):2974-2984.

[3] Abdul Wahab, H., Amir Hussin, M.A., Mohd. Nordin, N., Yusoff, Y.S., and Zainudin, W.N.R.A. "Foreign Currency Exposure and Hedging Practices: New Evidence from Emerging Market of ASEAN-4." Advanced Science Letter 23, no.5 (2017): 4939-4943.

[4] Jorion, P. "The exchange rate exposure of US multinationals." Journal of Business 63, (1990): 331-345.

[5] Bartram, S. M., and Bodnar, G.M. "Crossing the lines: The conditional relation between exchange rate exposure and stock returns in emerging and developed markets." Journal of International Money and Finance 31, (2012): 766-792.

[6] Chow, E.H., and Chen, H-L. "The determinants of exchange rate exposure: Evidence on Japanese firms." Pacific-Basin Finance Journal 6, (1998): 153-174.

[7] Aabo, T. "The importance of corporate foreign debt in managing exchange rate exposures in non-financial companies." European Financial Management 12, no.4 (2006): 633-649.

[8] Jeon, B. N., Zhu, L., \& Zheng, D. "Exchange rate exposure and financial crises: evidence from emerging Asian markets." Risk Management 19, no. 1 (2017): 53-71.

[9] Lan, L.-H., Chen, C.-C., \& Chuang, S.-S. "Exchange rate risk management: What can we learn from financial crises?" Economic Modelling 45, (2015): 187-192.

[10] Bernoth, K., \& Herwartz, H. (2019). "Exchange Rates, Foreign Currency Exposure and Sovereign Risk." DIW Discussion Papers, No. 1792. Deutsches Institut fur Wirtschaftsforschung (DIW), Berlin.

[11] Zarei, A., Ariff, M., \& Bhatti, M. I. The impact of exchange rates on stock market returns: new evidence from seven free-floating currencies. The European Journal of Finance 25, no. 14 (2019): 1-12.

[12] Eun, C. S.,\& Resnick, B. G. (1998). International Financial Management (2nd ed.). McGraw Hill.

[13] Harris, P., \& Kaur, S. "An Overview of Foreign Currency Exposure." Asian Journal of Empirical Research 3, no.8 (2013): 957-961.

[14] Mahadevan, S. (2017). "An Empirical Analysis of Foreign Exchange Exposure of CNX 100 Companies." International Journal of Financial Management 7, no.2 (2017): 1-9.

[15] Abdalla, I. S.A., and Murinde, V. "Exchange rate and stock price interactions in emerging financial markets: evidence on India, Korea, Pakistan and the Philippines."
Applied Financial Economics 7, no. 1 (1997): 25-35.

[16] Kho,B., and Stulz, R. M. "Banks, the IMF and the Asian crisis." Pacific-Basin Finance Journal 8, (2000):177-216.

[17] Parsley, D., and Popper, H. (2002). Exchange rate pegs and foreign exchange exposure in East Asia, Working Paper, Vanderbilt University and Santa Clara University,

[18] Kiymaz, H. (2003). "Estimation of foreign exchange exposure: An emerging market application." Journal of Mutlinational Financial Management 13, (2003): 71-84.

[19] Ito, T., Koibuchi, S., Sato, K., and Shimizu, J. (2015). "Exchange rate exposure and risk management: The case of japanese exporting firms." Journal of the Japanese \& International Economies 41 (2016): 17-29.

[20] Bank Negara Malaysia. (1994). Money \& Banking in Malaysia-35th Anniversary Edition 1959-1994. Kuala Lumpur: Bank Negara Malaysia.

[21] Hui-Nee, A. (2014). Risk management in Malaysian commercial banks. Paper presented at the UUM international conference on governance.

[22] Doidge, C., Griffin, J., \& Williamson, R. "Measuring the economic importance of exchange rate exposure." Journal of Empirical Finance 13, no. 4-5 (2006): 550-576.

[23] Ramasamy, B. Foreign Exchange Rate Exposure During a Financial Crisis: The Case of Malaysian multinationals. Division of Business and Management, University of Nottingham in Malaysia, 2000.

[24] Othman, N., Zaidi, M.A.S., Karim, Z.A. and Yusop, Z. (2015). "Impact of External and Domestic Shocks on Malaysia's Electronic and Electrical (E\&E) Export Demand." International Journal of Economics and Management, 9(Special Issue): 1-20.

[25] Wan Abdullah, W. R., J. Roudaki, and Clark, M. "The Evolution of the Islamic Capital Market in Malaysia." Paper presented at the Accounting History International Conference on Accounting and the State, Wellington, New Zealand, August 2010.

[26] Herzi (2018). An Overview of the Islamic Capital Market in Malaysia, unpublished Thesis, Universiti Sains Islam Malaysia (USIM).

[27] Yakcop, N. M. (2002). Islamic Financial Market Development: The Malaysian Strategy. Paper presented at the Kuala Lumpur International Islamic Capital Market Conference.

[28] Elfakhani, S., Hassan, M. and Sidani, Y. (2007), "Islamic Mutual Funds", in M. Kabir Hassan (eds.) Handbook of Islamic Banking, pp. 265-273, Edward Elgar: Cheltenham, UK

[29] Securities Commission of Malaysia (2004). Islamic Capital Market Review. Annual Report 2004, 20-28.

[30] Grewal, B. (2012) “Global Islamic Finance Forum 2012 Bridging Economies" Kuwait Finance House Research Report, Kuala Lumpur, Malaysia.

[31] Najeeb, S. F., \& Vejzagic, M. (2013). Development, Growth and Challenges of Islamic Capital Markets: Comparative Insights from the Malaysian, Indonesian, 
United Arab Emirates and Brunei Markets. Journal of Emerging Economies and Islamic Research, 1(3), 1-38.

[32] Mat Nor, F., Amir, S., Ainulashikin, M. \& Nur Ainna, R. "Revised Malaysia Syariah Screening: Its Impact on Islamic Capital Market." Research in World Economy 10, no. 1 (2019): 17-30.

[33] Abdul Rahman, A., Yahya, M.A., \& Mohd Nasir, M.H. "Islamic norms for stock screening a comparison between the Kuala Lumpur Stock Exchange Islamic Index and the Dow Jones Islamic Market Index." International Journal of Islamic and Middle Eastern Finance and Management 3, no. 3 (2010):228-240.

[34] Pok, W. C. "Analysis of Syariah quantitative screening norms among Malaysia Syariah-compliant stocks." Investment Management and Financial Innovations 9, no. 2 (2019): 69-80.

[35] Trinks, P.J., \& Scholtens, B. "The opportunity cost of negative screening in socially responsible investing." Journal of Business Ethics 140, no.2 (2017): 193-208.

[36] Securities Commission Malaysia. "List of Syariah-compliant Securities by the Syariah Advisory Council of the Securities Commission Malaysia." November (2019):1-35.

[37] Saiti B., Abdul Wahab, H., and Ahmad, K. (2017). Contracts, structures and computation mechanisms of Islamic bank retail financing products: A critical assessment. Islamic banking, Palgrave CIBFR Studies in Islamic Finance book series.

[38] Gencay, R., F. Selcuk and Whitcher, B. "Systematic risk and time scales." Quantitative Finance 3, (2003): 108-116.

[39] Gencay, R., Selcuk, F., and Witcher, B. "Multiscale systematic risk." Journal of International Money and Finance 24, (2005): 55-70.

[40] In, F. and Kim, S. "The hedge ratio and the empirical relationship between the stock and futures markets: A new approach using wavelet analysis." Journal of Business 79, (2006): 799-820

[41] Jensen, M. J. "Using wavelets to obtain a consistent ordinary least square estimator of the long-memory parameter." Journal of Forecasting 18, (1999): 17-32.

[42] Tkacz, G. "Estimating the fractional order of integration of interest rates using a wavelet OLS estimator." Studies in Nonlinear Dynamics and Econometrics 5, no.1 (2001): 114
[43] Whitcher, B. and M. J. Jensen. "Wavelet estimation of a local long memory parameter." Exploration Geophysics 31, (2000): 89-98.

[44] Ramsey, J. B. and Lampart, C. "The decomposition of economic relationships by time scale using wavelets: Expenditure and income." Studies in Nonlinear Dynamics and Economics 3, (1998): 23-42.

[45] Kim, S. and In, F. "The relationship between stock returns and inflation: New evidence from wavelet analysis." Journal of Empirical Finance 12, (2005): 435-444.

[46] Masih, M., \& Alzahrani, M., and Al-Titi, O. "Systematic risk and time scales: New evidence from an application of wavelet approach to the emerging Gulf stock markets." International Review of Financial Analysis 19, (2010): 10-18.

[47] Percival, D. B. and Walden, A.T. (2000). Wavelet Methods for Time Series Analysis. Cambridge, UK: Cambridge University Press.

[48] Gencay, R., F. Selcuk and Whitcher, B. (2002). An Introduction to Wavelets and Other Filtering Methods in Finance and Economics. London: Academic Press.

[49] Wan Suhaimi W. N., Abdul Wahab, H. and Md. Sum, R. Symmetric \& asymmetric exchange rate exposure Evidence from Malaysian non-financial firms." AIP conference proceedings 2138, no.1(2019): 050028.

[50] Abdul Wahab, H. "Does foreign currency derivative affect the variation of currency exposure? Evidence from Malaysia." Advanced Science Letters 23, no.5 (2017): 4934-4938.

[51] Wan Suhaimi W. N., Abdul Wahab, H. and Md. Sum, R. "The time-varying exposure of Malaysian non-financial firms using panel and OLS analyses." AIP conference proceedings 2138, no. 1(2019): 050029.

[52] Abdul Wahab, H. “Revisiting the Role of Bank's Capital, Loan Loss Provisioning and Risky Assets to Credit Risk in Malaysia: An Application of Dynamic Heterogenous Panel Technique" The Journal of Social Sciences Research Special Issue 6 (2018): 466-471.

[53] Sinaga, J.S., Muda, I and Silalahi, A.M. "The Effect of BI Rate, Exchange Rate, Inflation and Third Party Fund (DPK) on Credit Distribution and Its Impact on Non Performing Loan (NPL) on XYZ Commercial Segment Bank." Universal Journal of Accounting and Finance 8, no. 3, (2020): 55-64. DOI: 10.13189/ujaf.2020.080301 